Ice was offered, but he would not look at it. A small piece of sponge dipped in water was then tried, and he succeeded in getting it into his mouth, but it was immediately ejected, and he became very excited, and could hardly be held or induced to remain in bed. $\mathbf{A}$ viscid and tenacious white mucus now became secreted, and he spat all over the room. His favourite position was on his hands and knees. Occasionally he would calm down, and was profuse in his apologies for being rude. Permitted the hypodermic injection of seventeen grains of chloral.

On the 11th I found he had not slept, but was now calmer; had such a dread of the doctors, he swore he would not have them near, and told his wife to say he had gone out for a walk. He writhed and twisted about the bed, catching hold of whatever came in his way, cursing and swearing, threatening to murder; then, for a few seconds, he would again become calm, and, whilst carrying on a conversation, would suddenly break off in the middle of it, crying out, "It is coming again," "Shut the door," "Be quiet." Had lost command over his bladder during the night. At 8 P.M. a messenger came to say he was dying, and on arrival I found that they had been obliged to strap him down in the bed. His face was congested, his lips livid, pupils widely dilated, teeth firmly clenched, saliva flowing from his mouth, pulse scarcely perceptible, respiration sighing, and in a few seconds entirely ceased. No post-mortem was permitted.

The interesting features in the case are the lengthened period of incubation, the determination on the part of the patient to overcome the spasm, and his denial that the bite of the dog had anything to do with his illness, although he afterwards admitted to his brother that at the time he was bitten it made a profound impression on him, and he had never been able to shake it off. He died in the full belief the dog was alive, and had never been mad. Marked benefit was derived from the hypodermic injection of chloral, and the sole reason for not administering it more frequently was the difficulty in persuading the patient to submit to it; although concentrated, no irritant effect was produced by it. It is impossible to say how much bromide of potassium was taken, as he put it on his tongue, a few grains at a time, and probably some of it was lost. He stated, however, that it gave a feeling of relief to the mouth. In conclusion, I believe the hypodermic injection will be found the most rational mode of treatment of this dreadful and, so far, incurable malady, whatever the drug used may be.

St. Helen's, Lancashire.

\section{CASE OF DORSAL DISLOCATION OF THE OS FEMORIS.}

By Staff-SuRgeon RICHARD L. B. HEAD, R.N.

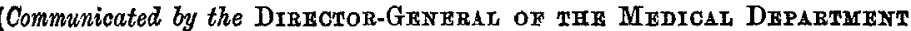
OF THE NAVY.)

R. B-, aged thirty-one, plumber's mate, when stepping suddenly on one side to avoid a man who was rushing violently against him, slipped off one of the racers on which the forecastle pivot gun works, and falling heavily, found, when placed on his legs again, he could not reach the deck with the beel of his right foot. He was at once taken to the sick bay, and I saw him almost immediately.

He did not complain of pain, but stated that he felt something "snap" in his right hip when he struck the deck. On examination, the whole limb was everted and fixed; there was shortening to the extent of one inch and three-quarters ; the head of the femur could be distinctly felt over the sciatic notch; there was no crepitation. Immediate steps were taken for the reduction, the patient placed fully under chloroform, and manipulation employed as directed by Dr. Reed, of Rochester, U.S. (Erichsen). I found no difficulty in the operation, the head of the bone slipping back into the acetabulum at the first attempt.

In the remarks on a case described in ThE LANCET of the 5th February, 1876, it is stated that " the occurrence of eversion of the limb in cases of dorsal dislocation of the head of the femur is quite exceptional." I deem it of interest to send a record of the above.

\section{A ettirror}

\section{H OSPITAL PRACTICE, BRITISH AND FOREIGN.}

Nulla autem est alia pro certo noscendi via, nisi quamplurimas et morborune. et dissectionum historias, tum aliorum, tum proprias collectas habere, et
inter so comparare.-Morgagn I De Sed. et Caus. Morb., lib.iv. Procemium.

\section{KING'S OOLLEGE HOSPITAL.}

CASE OF CLEFT THROUGH THE HARD AND SOFT PALATE.

(Under the care of Mr. HeNRY SMrTH.)

A DIFFERENCE of opinion still exists respecting the best mode of closing a cleft in the hard palate. The choice lies between two operations: that proposed and practised by Langenbeck; and that suggested by Dieffenbach, and more recently, but independently, employed by the late Sir Wm. Fergusson. In the former, a band of tough tissue, consisting of periosteum and mucous membrane, is raised from the bone on each side of the cleft, and fixed together by sutures in the middle line opposite the opening in the palate; in the latter, the periosteum is not separated from the bone, but the hard palate is perforated with a chisel about a quarter of an inch from the edge of the cleft on each side, and the two pieces of bone thus detached are prised towards the middle line and fixed there by stitches, whereby a bony covering is formed. Sir William Fergusson had an extensive and favourable experience of the latter plan, which is now always followed at King's College Hospital. In this operation the soft parts are treated according to Sir William's original method of first dividing the levator palati muscles. Occasionally some necrosis of the bone has occurred at the place of splitting, and at times the operation has been attended with considerable bleeding. In a very bad case of cleft both in the hard and soft palate, in a young woman under the care of Mr. Henry Smith, this operation entirely failed in consequence of the severe bleeding which resulted during the process of splitting the bones and dividing the muscles. In this case the muscles had been divided, as usual, first; and during the whole operation more or less bleeding was going on here. Considerable hæmorrhage also occurred from the use of the chisel. In order to avoid this bleeding, Mr. Smith determined on the next occasion to pare the edges of the cleft first; then to split the palate after having introduced the threads through the edges, and immediately to stuff the gaps with lint; lastly, to divide the levator palati muscles before finally closing the wound.

W. SCollege Hospital on August 21st. He was a weakly youth, and had been operated on for hare-lip when he was six weeks old, by the late Sir W. Fergusson. A cleft, though not very wide, extended throughout nearly the whole of the palate, hard and soft, and the vomer was attached to the left side of the fissure. The operation was performed on August 25th under chloroform. Mr. Henry Smith first pared the edges of the entire cleft, then drilled holes through the edges of the hard palate and inserted the threads. The bone was then split on each side, and forcibly pushed together towards the median line, and the resulting holes were at once stuffed with lint, and all bleeding stopped. The levator palati on each side was then quickly divided, and sutures being passed through the edges of the soft palate, the whole was drawn together. The bleeding was comparatively slight. On the 28 th the parta were looking very healthy. An aperient was given, and plenty of fluid nourishment. On the 29 th the stitches were removed, and the whole was found to be firmly united, with: the exception of the uvula. As, however, the patient im. proved and was enabled to take plenty of food, union. went on there, and when he was dismissed from the hospital, two weeks af ter the withdrawal of the stitches, there. was perfect adhesion throughout and already an improvement in the voice.

Mr. Henry Smith lays great stress upon the importance. of watehing the after-treatment, on giving an aperient on the third day so as to correct the morbid secretions which 